\section{Stocking Rangelands on the Rio Puerco in New Mexico ${ }^{1}$}

\author{
EARL F. ALDON AND GEORGE GARGIA
}

\begin{abstract}
Hydrologist and Forestry Research Technician, Rocky Mountain Forest and Range Experiment Station, 2 Albuquerque, New Mexico.
\end{abstract}

\section{Highlight}

A stocking table developed on an experimental range area in the $\mathbf{R}$ io Puerco drainage can be used to determine stocking rates in animal units per section. Estimates are based on perennial grass forage production and utilization percentages and are applicable to a large portion of semidesert ranges in central New Mexico.

Stocking levels, utilization percentages, and perennial grass forage production were recorded from 1958 through 1969 on the San Luis Experimental Watersheds in the Rio Puerco Basin, 58 miles northwest of Albuquerque, New Mexico. Over two-thirds of the 3,900,000 acres of the Rio Puerco is composed of rangelands similar to those in the experimental watersheds. From 12 years of data on part of the watershed, we have developed tables to use as guidelines for stocking semidesert ranges in central New Mexico, where summer deferment is practiced. These are applicable on semidesert ranges found on most of the Rio Puerco drainage.

The portion of the watershed used for this study is a 525-acre experimental range unit, pasture II, in the transition zone between woodland and semidesert grassland (Aldon, 1964). Cattle grazed the area each year from November 1 through April 30. Principal forage species, in descending order of cattle preference (Aldon and Garcia, 1967), are alkali sacaton (Sporobolus airoides (Torr.) Torr.), galleta (Hilaria jamesii (Torr.) Benth.), and blue grama (Bouteloua gracilis (H.B.K.), Lag. ex Steud.).

\section{Developing the Tables}

Tables were developed by computing multiple regressions (Reid et al., 1963), based on various combinations of utilization, production, and stocking level (Table 1). Utilization percentages for the combined species $\left(\mathrm{U}_{2}\right.$ in Table 1 ) were determined by adding weighted utilization figures for each of the three individual species. The weighted value

\footnotetext{
${ }^{1}$ Study conducted in cooperation with Bureau of Land Management, U. S. Department of the Interior, Albuquerque, New Mexico. Manuscript received September 24, 1970; accepted for publication December 7, 1970.

${ }^{2}$ Forest Service, U. S. Department of Agriculture, with central headquarters maintained at Fort Collins in cooperation with Colorado State University; research reported here was conducted at Albuquerque, New Mexico, in conperation with the University of New Mexico.
}

was determined by multiplying the utilization figure of each species, as measured after the growing season, by a constant value representing the contribution of that species to the grass production of that season. The constant value is determined from the weight of the total grass production. This value was 0.33 for alkali sacaton, 0.53 for galleta, and 0.14 for blue grama (Aldon and Garcia, 1967). Thus galleta yields over half of the total grass yield (by weight) and alkali sacaton one-third.

An example of how the weighted utilization $\left(\mathrm{U}_{2}\right)$ was computed for the 1968-69 season follows:

\begin{tabular}{lcccc} 
& $\begin{array}{c}\text { Constant } \\
\text { value }\end{array}$ & \multicolumn{2}{c}{$\begin{array}{c}\text { Utilization } \\
\text { for that year }\end{array}$} & \\
Alkali sacaton & 0.33 & $\times$ & 54.0 & $=17.8$ \\
Galleta & 0.53 & $\times$ & 21.3 & $=11.3$ \\
Blue grama & 0.14 & $\times$ & 10.9 & $=1.5$ \\
\multicolumn{1}{c}{ Weighted utilization $\left(U_{2}\right.$ in Table 1$)$} & $=30.6$
\end{tabular}

Utilization on the San Luis area depends on many interrelated factors-class of livestock, topography, fencing, and water location (Hickey and Garcia, 1964). Also, species preference plays an important part in utilization of available forage. In the Rio Puerco basin, a weighted utilization of 21 to $31 \%$, plus summer deferment, helped improve the range resource (Aldon and Garcia, 1967). Data on utilization values for galleta that may be expected at different levels of utilization of alkali sacaton (Table 2) were developed by relating galleta utilization with alkali sacaton utilization, by regression analyses. The regression was significant (at $1 \%$ level) for the 12 years of data used. Utilization values for blue grama (Table 2) are estimates based on experience.

Table 1. Utilization (\%) and grass production (lb./acre, air dry) for alkali sacaton and a combination of alkali sacaton, galleta, and blue grama, with stocking levels per section on pasture II, San Luis experimental watershed, November 1 through April 30, 1958-69.

\begin{tabular}{|c|c|c|c|c|c|c|}
\hline \multirow{3}{*}{$\begin{array}{l}\text { Grazing } \\
\text { period } \\
\text { (Nov.- } \\
\text { April) }\end{array}$} & \multirow{2}{*}{\multicolumn{2}{|c|}{ Utilization }} & \multirow{2}{*}{\multicolumn{2}{|c|}{ Production }} & \multicolumn{2}{|c|}{ Stocking level } \\
\hline & & & & & & \\
\hline & $\begin{array}{c}\text { Alkali } \\
\text { sacaton } \\
\left(\mathbf{U}_{1}\right)\end{array}$ & $\begin{array}{l}\text { Three } \\
\text { grasses } \\
\left(\mathbf{U}_{2}\right)^{1}\end{array}$ & $\begin{array}{c}\text { Alkali } \\
\text { sacaton } \\
\left(\mathbf{P}_{1}\right)\end{array}$ & $\begin{array}{c}\text { Three } \\
\text { grasses } \\
\left(\mathbf{P}_{2}\right)\end{array}$ & $\begin{array}{c}\text { of } \\
\text { animals } \\
\left(S_{1}\right)\end{array}$ & $\begin{array}{c}\text { Animal } \\
\text { units } \\
\left(S_{2}\right)\end{array}$ \\
\hline $1958-59$ & 48.2 & 31.9 & 87.7 & 231.2 & 15 & 15 \\
\hline $1959-60$ & 70.0 & 35.6 & 55.3 & 187.6 & 12 & 12 \\
\hline $1960-61$ & 44.6 & 21.6 & 51.7 & 150.7 & 9 & 9 \\
\hline $1961-62$ & 34.2 & 14.4 & 72.0 & 229.0 & 12 & 12 \\
\hline $1962-63$ & 46.8 & 22.8 & 88.0 & 304.0 & 10 & 10 \\
\hline $1963-64$ & 49.5 & 23.4 & 123.2 & 264.8 & 7 & 7 \\
\hline $1964-65$ & 39.3 & 21.3 & 289.3 & 475.8 & 9 & 9 \\
\hline $1965-66$ & 52.3 & 24.4 & 255.3 & 395.7 & 12 & 16 \\
\hline $1966-67$ & 52.6 & 22.5 & 295.1 & 495.9 & 19 & 12 \\
\hline $1967-68$ & 47.6 & 26.8 & 276.4 & 481.8 & 20 & 20 \\
\hline $1968-69$ & 54.0 & 30.6 & 292.6 & 524.4 & 45 & 27 \\
\hline
\end{tabular}

${ }^{1}$ Weighted utilization percentages based on production of alkali sacaton, galleta, and blue grama. 
Table 2. Weighted utilization percentage for alkali sacaton, galleta, and blue grama, developed by relating galleta with alkali sacaton utilization by regression analysis, ${ }^{1}$ and and by estimating blue grama. ${ }^{2}$

\begin{tabular}{cccc}
\hline \hline $\begin{array}{c}\text { Alkali sacaton } \\
\left(\mathbf{U}_{\mathbf{\Lambda}}\right)\end{array}$ & Galleta $\left(\mathbf{U}_{\mathrm{i}}\right)$ & Blue grama $\left(\mathbf{U}_{\mathrm{B}}\right)$ & $\begin{array}{c}\text { Three grasses } \\
\left(\mathbf{U}_{2}\right)\end{array}$ \\
\hline 35 & 16 & 3 & 20 \\
40 & 18 & 5 & 23 \\
45 & 19 & 5 & 26 \\
50 & 21 & 10 & 29 \\
55 & 22 & 10 & 31 \\
60 & 23 & 12 & 34 \\
65 & 25 & 12 & 36 \\
70 & 26 & 14 & 39
\end{tabular}

${ }^{1}$ Value for galleta determined from regression $\mathrm{U}_{\mathrm{a}}=7.02+0.271$ $\mathrm{U}_{\mathrm{A}}$ (significant at $1 \%$ level).

"Value estimated; regression not significant.

Utilization and production data were used to compute the stocking levels $\left(\mathrm{S}_{2}\right)$, shown in Table 3.

Pastures adjacent to the experimental watershed were used to check the validity of the computations:

$\begin{array}{lcc}\text { Pasture No. } & \text { I } & \text { III } \\ \text { Pasture size (sq. miles) } & .87 & .53 \\ \text { Production for year of test (lb./acre, air dry) } & 380 & 272 \\ \text { Stocking per section (animal units) } & 17 & 19 \\ \text { Measured utilization (\%) } & & \\ \quad \text { Alkali sacaton } & 57.0 & 59.4 \\ \quad \text { Galleta } & 15.1 & 16.9 \\ \quad \text { Blue grama } & 2.4 & .1 \\ \text { Weighted utilization of all species (\%) } & 27.1 & 28.7 \\ \text { Stocking from formula (animal units) } & 16 & 20\end{array}$

Thus formulas provided stocking levels very close to those actually used for the desired utilization.

\section{Using the Tables}

1. Choose two or three representative sections of land in an allotment. These tables are for semidesert ranges composcd principally of alkali sacaton, galleta, and blue grama in central New Mexico.

2. Measure production of the three key species on these sections.

3. Decide on the utilization percentage $\left(\mathrm{U}_{2}\right)$ that you will accept; consult Table 2 for assistance in selecting $\mathrm{U}_{2}$ : After you have selected an acceptable level of alkali sacaton utilization,
Table 3. Stocking levels (animal units per section) for November-April grazing period, computed from herbage production (lb./acre, air-dry), and weighted utilization (\%).

\begin{tabular}{crrrrrrr}
\hline \hline $\begin{array}{c}\text { Weighted } \\
\text { utilization } \\
\left(\mathbf{U}_{2}\right)\end{array}$ & \multicolumn{6}{c}{ Production $\left(\mathbf{P}_{2}\right)$} \\
\cline { 2 - 8 } & 200 & 250 & 300 & 350 & 100 & 150 & 500 \\
\hline 20 & 1 & 2 & 3 & 4 & 5 & 6 & 7 \\
23 & 7 & 8 & 9 & 10 & 11 & 12 & 13 \\
26 & 13 & 14 & 15 & 16 & 17 & 18 & 19 \\
29 & 19 & 20 & 21 & 22 & 23 & 24 & 25 \\
31 & 23 & 24 & 25 & 26 & 27 & 28 & 29 \\
34 & 28 & 29 & 30 & 31 & 32 & 33 & 34 \\
36 & 32 & 33 & 34 & 35 & 36 & 37 & 38 \\
39 & 38 & 39 & 40 & 41 & 42 & 43 & 44 \\
\hline
\end{tabular}

and know the galleta and blue grama utilization to be expected at this level, read from Table 2 the weighted utilization figure $\left(\mathrm{U}_{2}\right)$ that should be used in Table 3. (Values in Table 3 are on a per-section basis, and are conservative.)

4. From Table 3, determine the stocking level in animal units per section.

5. Adjust animal unit numbers to fit the class of livestock to be grazed.

6. Compute animal numbers for the allotment.

A computer program prepared in basic language for making these computations is available from the authors. The program provides stocking levels in animals per square mile corrected for class of livestock and months grazed at a cost of about $\$ 1 /$ allotment.

\section{Literature Cited}

Aldon, EARL F. 1964. Ground-cover changes in relation to runoff and erosion in west-central New Mexico. Rocky Mt. Forest and Range Exp. Sta., Ft. Collins, Colo. U.S. Dep. Agr., U. S. Forest Serv. Res. Note RM-34, 4 p.

Aldon, Earl F., and George Garcia. 1967. Summer deferred grazing can improve deteriorated semidesert ranges. Rocky Mt. Forest and Range Exp. Sta., Ft. Collins, Colo. U. S. Dep. Agr., U. S. Forest Serv. Res. Note RM-95, 3 p.

Hickey, Wayne G., JR., and George Garcia. 1964. Range utilization patterns as affected by fencing and class of livestock. Rocky Mt. Forest and Range Exp. Sta., Ft. Collins, Colo. U. S. Dep. Agr., U. S. Forest Serv. Res. Note RM-21, 7 p.

Reid, Elbert H., Jacob L. Kovner, and S. Clark Martin. 1963. A proposed method of determining cattle numbers in range experiments. J. Range Manage. 16:184-187.

\section{Specialists in Quality NATIVE GRASSES}

Wheatgrasses - Bluestems • Gramas • Switchgrasses • Lovegrasses • Buffalo • and Many Others

We grow, harvest, process these seeds

Your Inquiries

Appreciated

SHARP BROS. SEED CO.

Phone 398-2231

HEALY, KANSAS 